\title{
IMPACT OF CERTAIN BAITS FOR CONTROLLING ANACRIDIUM AEGYPTIUM (L.), UNDER LABORATORY AND FIELD CONDITIONS.
}

\author{
Sayed, M.M. El- Garhy \\ Plant Protection Res. Institute Dept. Of Biological control Doki, Giza
}

\begin{abstract}
Quick lime, Beauveria bassinet, Metarhisium anisopliae and Hostathion [triazophos] were used as poisonous baits mixed with molasses and wheat brain (2: 1: 4) against Anacridium aegyptium adults under laboratory and field conditions. Quick lime was the most efficient material against $A$. aegyptium after $72 \mathrm{hr}$. when used at the quantity of $1.75 \mathrm{~kg}$ and achieved $90 \%$ mortality, followed by both $M$. anisopliae at the concentration of $1.75 \times 10^{7}$ spores $/ \mathrm{ml}$., Hostathion at the concentration of $1.75 \mathrm{ml} / 1$ and $B$. bassinet at the concentration of $1.75 \times 10^{7}$ spores $/ \mathrm{ml}$.compared to the control. Starved adults were exposed to the concentrations of $\mathrm{LC}_{50}$ without plants in the laboratory for 24, 48 and $72 \mathrm{hr}$. Quick lime also achieved higher mortality (54\%) after 72 hrs. compared with any entomopathogen and Hostathion. In the field trails, A. aegyptium were exposed to double concentrations of the quick lime, fungal entomopathogen, and Hostathion for 2, 4 and 6 days. Fewer grams of quick lime and Hostathion insecticide semi-hard cake were consumed and achieved higher mortality after 6 days compared with the two other biological agents and the control.
\end{abstract}

Key words: Beauveria bassinet, Metarhisium anisopliae, Hostation, [triazophos], Anacridium aegyptium.

\section{INTRODUCTION}

Anacridium aegyptium; is well known as dangerous pest against many crops all over the world (Roditakis et al 2002). This insect is capable of forming large swarms, which invade many countries and causes catastrophic damage to cultivated vegetations, which is difficult to control, especially when populations are epidemic in proportion, (Anjum et al 2001). This insect pest feeds on the leaves, but its occurrence on the plant is rare (Goeden 1976). In Fayoum Governorate, Egypt. The present study was made 2009 to evaluate the effect of quick lime (calcium oxide), the fungus Beauveria bassiana the fungus Metarhizium anisopliae A. aegyptium and the chemical insecticide Hostathion [triazophos] to protect our crops from damage. Baits of each in molasses and wheat bran were evaluated against the adult of $A$. aegyptium under laboratory and field conditions.

\section{MATERIALS AND METHODS}

\section{I- Laboratory studies}

\section{A. Stock cultures}

\section{1-A.aegyptium:}

Adults of the $A$. aegyptium were collected from heavily invested tomato crops and reared in the laboratory on tomato seedlings, 30 days old, in pots of $10 \mathrm{~cm}$ for three generations according to (Maud et al 1965).

\section{2- Entomopathogenic fungi:}

The entomopathogenic fungi, Beauveria bassiana, and Metarhizium anisopliae were isolated from collected dead adults of Anacridium aegyptium, (Rosa and Alain 2004). Serial dilutions were prepared to obtain the desired

Fayoum J. Agric. Res. \& Dev., Vol.25, No.1, January, 2011 
concentrations. of $10^{5}, 10^{6}$ and $10^{7}$ conidia /ml for B. bassiana, and $1 \times 10^{5}$, $1.5 \times 10^{6}$ and $1.75 \times 10^{7}$ spores / $\mathrm{ml}$ for M. anisopliae.

A pelleted semi- hard cake baits consisted of quick lime, sugar can molasses and wheat bran at the rates of $2 \mathrm{~L}: 1 \mathrm{~L}$ :and $4 \mathrm{~kg}$ ) was prepared.

The laboratory experiments were carried out on tomato seedlings in 10 $\mathrm{cm}$ plastic pots kept at room conditions.

\section{B. Treatments:}

Quick lime bait was used at $1.0,1.5$ and $1.75 \mathrm{~kg}$, each was mixed with sugar can molasses and wheat bran at the rates of ( $2 \mathrm{~L}: 1 \mathrm{~L}$ :and $4 \mathrm{~kg}$ ).

$B$. bassiana and $M$. anisopliae. Were used at $1 \times 10^{5}, 1.5 \times 10^{6}$ and $1.75 \times 10^{7}$ spores / ml. each was mixed with sugar can molasses and wheat bran at the rates of ( $2 \mathrm{~L}: 1 \mathrm{~L}:$ and $4 \mathrm{~kg}$ ).

Hostathion was used at 1.0, 1.5 and 1.751. each was mixed with sugar can molasses and wheat bran at the rates of ( $2 \mathrm{~L}: 1 \mathrm{~L}:$ and $4 \mathrm{~kg}$ ).

The experiments were carried out on Castle Rock tomato seedlings cultivated in plastic pots of $10 \mathrm{~cm}$.

C. Efficiency tests:

\section{Effect of quick lime:}

Thirty adults of Anacridium aegyptium in three equal groups were exposed to 24,48 , and $72 \mathrm{hrs}$. Insects were kept in cages on potted tomato plants provided each with 25 gr. quick lime at the quantity of (1. 1.5 and 1.75 $\mathrm{kg})$.

\section{Effect of chosen fungi:}

Thirty adults of Anacridium aegyptium in three equal groups were exposed for 24, 48, and $72 \mathrm{hrs}$. Insects were kept as above and provided each with 25 gr. of one of the previous semi-hard cakes of $M$. anisoplea and $B$. basiana individually.

\section{Effect of Hostathion [triazophos] insecticide:}

Thirty adults of Anacridium aegyptium in three equal groups were exposed for 24,48 , and $72 \mathrm{hrs}$. Insects were kept as above were provided each with 25 gr. Hostathion semi-hard cakes.

New pelleted poisonous semi-hard cakes of Hostathion were prepared by mixing the sub lethal concentration at the ratio of (2:1:4) to which $A$. aegyptium starved adults were exposed in cages. Daily consumption of these adults was calculated.

The researcher quantified the effects of sub lethal concentration $\left(\mathrm{LC}_{50}\right)$ of quick lime and other sub lethal concentrations of the microbial organisms and Hostathion insecticide by (EPA) Probit Analysis Program was used for calculating LC/EC values Version 1.5 on a number of $A$. egypticum fitness parameters. New cakes of each of the quick lime, entomopathogenic fungi, and hostation were prepared for estimating the freely consumption of the starved adults of $A$. egypticum for 24,48 and $72 \mathrm{hr}$, by mixing the sub lethal concentration at (2:1: 4) and placed in the cages, each with ten adults of $\boldsymbol{A}$. aegypticum as a replicate. Daily consumption of these cakes was calculated.

\section{II-Field trials:}

In the field, an area of $175 \mathrm{~m}^{2}$ in Fayoum district was equally divided into three replicates as control for each treatment. Each has four beds $(1 \mathrm{x} 1 \mathrm{~m})$. Three doubled concentrations of each tested material were used as follows; quick lime pelleted semi-hard cakes $(2,3$ and $3.5 \mathrm{~kg})$, Metarhisium anisopliaee and Beauveria. bassiana $\left(2 \times 10^{5}, 3 \times 10^{6}\right.$ and $\left.3.5 \times 10^{7}\right)$ and Hostathion 2, 3 and 3.5/L. The control was untreated and distributed

Fayoum J. Agric. Res. \& Dev., Vol.25, No.1, January, 2011 
randomly. The beds were transplanted by castle rock tomato from Peto Seed Co. Each bed was planted on both sides at distances of $10 \mathrm{~cm}$ and covered by black shade netting. Ten adults of A. aegyptium were exposed per bed. Semihard cake of the mixture of the quick lime and molasses were applied on the beds at distances of ten $\mathrm{cm}$. Each of the other mixtures; entomopathogenic fungi and the Hostathion pesticide, were applied on beds. The field of this trial was inspected after 2, 4 and 6 days of treatment. Dead adults of A. aegyptium were collected in paper bags and counted.

\section{III- Statistical analysis:}

The data were analyzed using Probit analysis (Finny, 1952). LC $_{50}$ values were estimated for treatments. Analysis of variance (ANOVA) and LSD values were obtained at 0.05 level, using SAS program (SAS Institute, 1988). Statistical calculation was done through SPSS 11 for windows computer program to determine the Correlation and Regression Co-Efficient (r).

\section{RESULTS AND DISCUSSION}

\section{A- Efficiency of quick lime baits:}

As shown in table (1) and figs (1,2 and 3 ), death rate of A. aegyptium adults after 24, hr were 65, 67 and $68 \%$ upon exposure to bait at the concentrations of $1,1.5$, and $1.75 \mathrm{~kg}$. of the quick lime, respectively, with the consumption of 6.0. 5.5 and 4.5 gr. After $48, \mathrm{hr}$.the death rates were 70,76 and $82 \%$.with reductive consumption of $6.3,6.0$ and $5.1 \mathrm{gr}$. After $72 \mathrm{hr}$., these rates increased to 80,85 and $90 \%$ with the consumption of $6.6,6.3$ and 5.6 grams of the bait. Adults consumed 8.5, 8.9 and 9.5 grams of the bait in 24, 48 and $72 \mathrm{hr}$, respectively, with $0 \%$ death rates in the control. Calculated $\mathrm{LC}_{50}$ was $54.5,113.1$ and 0.449 .2 after 24,48 and $72 \mathrm{hr}$, respectively.

Table (2): shows that death rate of $A$. aegyptium adults after 24 , hr were 31 , 42 and $51 \%$ upon expose use to prepared bait at the concentrations of $\left(\mathrm{Lc}_{50}\right)$ of the quick lime at $1.0,1.5,1.75 \mathrm{~kg}$., respectively, with the consumption of 7.0. 6.8 and 6.5 gr. After 48, hr. the death rates were 34, 45 and $52 \%$.with reductive consumption of 7.5, 6.8 and 6.6 gr. After $72 \mathrm{hr}$. these rates increased to 41,46 and $54 \%$ with the consumption of $8.0,6.3$ and 6.1 grams of the bait. Adults death rates were $0 \%$ in the control and consumed 16.5, 20.0 and 23.9 grams of the bait in 24, 48 and $72 \mathrm{hr}$, respectively.

\section{B-Efficiency of Beauveria bait:}

Table (1) and figs (1, 2 and 3): showed that the death rate of $A$. aegyptium adults after $24, \mathrm{hr}$ were 45,50 and $55 \%$ upon exposure use to bait at the concentrations of $1 \times 10^{5}, 1.5 \times 10^{6}$, and $1.75 \times 10^{7}$ spores $/ \mathrm{ml}$. of Beauveria bassiana, respectively, with the consumption of 5.6, 6.6 and 6.8 gr. After 48, hr. the death rates were 53, 55 and $57 \%$.with consumption of $6.6,6.8$ and 7.0 gr. After $72 \mathrm{hr}$. These rates increased to 55, 58 and $60 \%$ with the consumption of 6.8, 7.2 and 7.5 grams of the bait, while adults death rates were $0 \%$ in the control and the consumed baits were 8.5, 8.9 and 9.5 grams in 24, 48 and 72 $\mathrm{hr}$, respectively,.Calculated $\mathrm{LC}_{50}$ was $1.4 \times 10^{4}, 0.6 \times 10^{3}$ and $0.5 \times 10^{5}$ after 24,48 and $72 \mathrm{hr}$, respectively.

Death rate of $A$. aegyptium adults after $24, \mathrm{hr}$ were 22,22 and $35 \%$ upon expose use to prepared bait at the concentrations of $\mathrm{LC}_{50}$ of $1 \times 10^{5}, 1.5 \times 10^{6}$, and $1.75 \times 10^{7}$ spores $/ \mathrm{ml}$. of Beauveria bassiana respectively, with the consumption of $9.5,9.7$ and 9.9 gr. After 48 , hr. the death rates were 26, 32 and $39 \%$.with consumption of 10.0, 10.4 and 10.6 gr. After $72 \mathrm{hr}$. these rates

Fayoum J. Agric. Res. \& Dev., Vol.25, No.1, January, 2011 
Table 1

Fayoum J. Agric. Res. \& Dev., Vol.25, No.1, January, 2011 


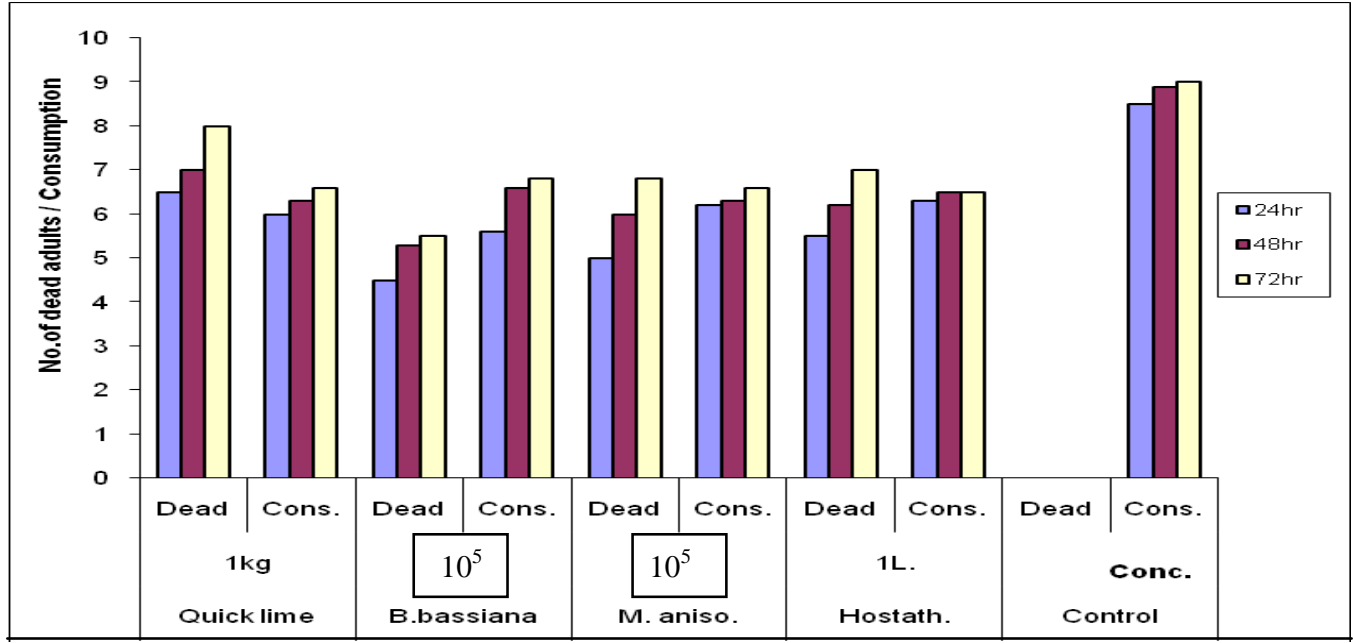

Fig (1): Potency of quick lime, M. anisopliae, B. bassiana and Hostathion and consumed quantities by the adults of $A$. aegyptium,n the laboratory, at different concentrations.

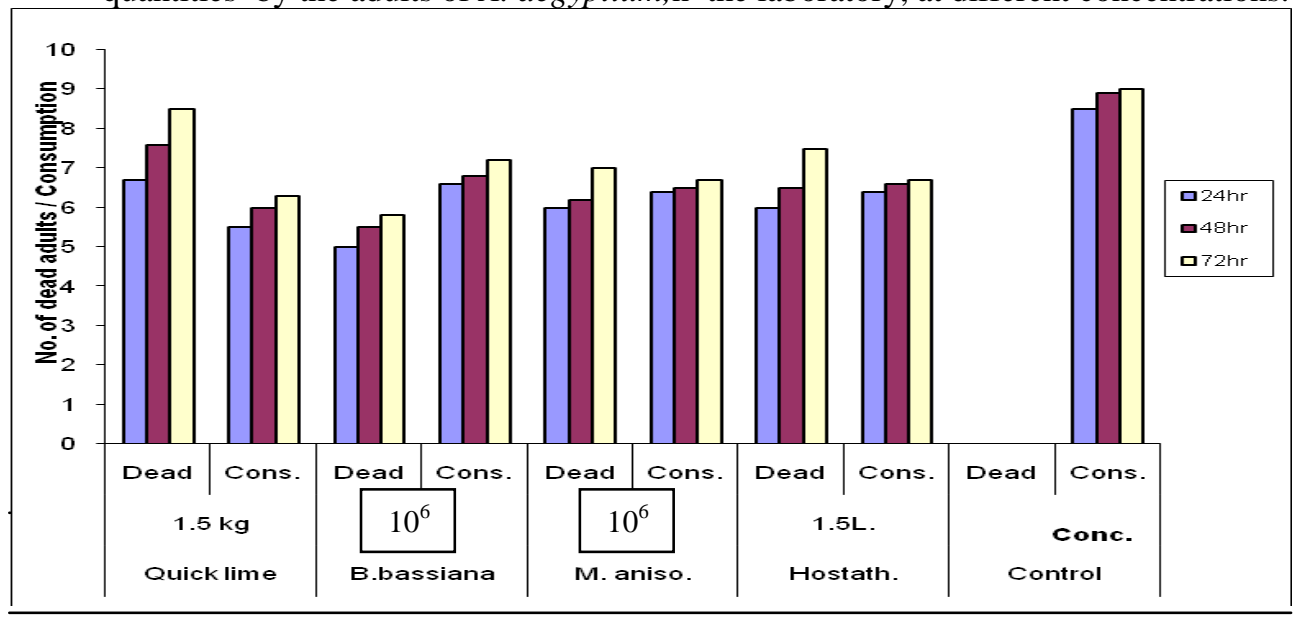

Fig (2): Potency of quick lime, M. anisopliae, B. bassiana and Hostathion and consumed quantities by the adults of Anacridium aegyptium, in the laboratoryat different concentrations.

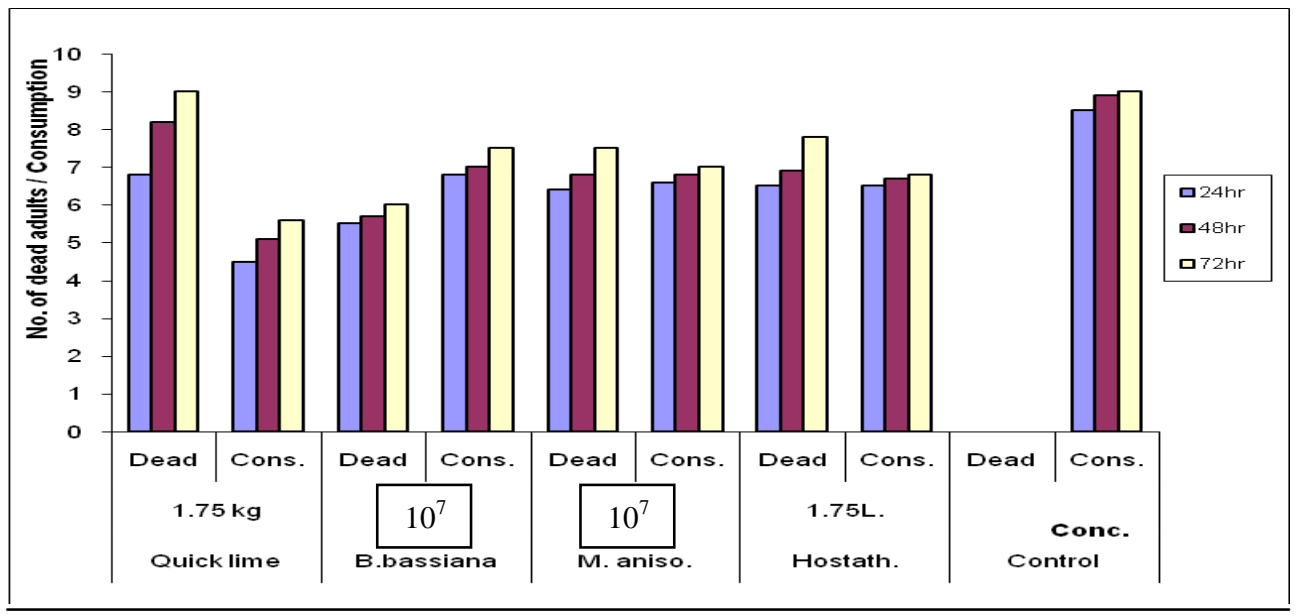

Fig (3): Potency of quick lime, M. anisopliae, B. bassiana and Hostathion and consumed quantities by the adults of Anacridium aegyptium in the laboratory at different concentrations.

Fayoum J. Agric. Res. \& Dev., Vol.25, No.1, January, 2011 
Table 2

Fayoum J. Agric. Res. \& Dev., Vol.25, No.1, January, 2011 
increased to 35,44 and $50 \%$ with the consumption of $12.0,12.3$ and 12.5 grams of the bait while the adults death rates were $0 \%$ in the control and the consumed bait were 17.5, 19.0 and 21.4 grams in 24,48 and $72 \mathrm{hr}$, Table. 2., respectively.

\section{C -Efficiency of Metarhizium bait:}

Death rate, of $A$. aegyptium adults after $24, \mathrm{hr}$ were 50, 60 and $64 \%$ upon exposure to bait concentrations of $1 \times 10^{5}, 1.5 \times 10^{6}$, and $1.75 \times 10^{7}$ spores / $\mathrm{ml}$ of Metarhizium anisopliae, respectively, with the consumption of 6.2.6.4 and 6.6 gr. After 48, hr. the death rates were 60, 62 and $68 \%$.with reduced consumption of $6.3,6.5$ and $6.8 \mathrm{gr}$. After $72 \mathrm{hr}$. these rates increased to 68,70 and $75 \%$ with the consumption of $6.6,6.7$ and 7.0 grams of the bait. Adults death were $0.0 \%$ in the control that consumed $8.5,8.9$ and 9.5 grams of the bait in 24, 48 and $72 \mathrm{hr}$, respectively, with $0 \%$ death rates in the control. Calculated $\mathrm{LC}_{50}$ values (Table 1) were $1 \times 10^{3}, 8 \times 10^{2}$ and $7 \times 10^{2}$ after 24,48 and $72 \mathrm{hr}$, respectively.

Death rate of $A$. aegyptium adults after 24 , $\mathrm{hr}$ were 28,41 and $42 \%$ upon exposure to prepared bait at the concentrations of $\mathrm{LC}_{50}$ of $1 \times 10^{5}, 1.5 \times 10^{6}$, and $1.75 \times 10^{7}$ spores / $\mathrm{ml}$ of Metarhizium anisopliae, respectively, with the consumption of 10.5. 10.6 and 10.8 gr. After 48 , hr. the death rates were 30 , 34 and $45 \%$.with increased consumption of 12.1, 13.6 and 14.2 gr. After $72 \mathrm{hr}$. these rates increased to 41,46 and $54 \%$ with the consumption of $12.5,13.4$ and 14.6 grams of the bait. Adults consumed 18.5, 20. and 22.3 grams of the bait in 24, 48 and $72 \mathrm{hr}$, with $0 \%$ death rates in the control, table 2, respectively .

In this resdect, (Shah et al 1997) found that M. anisopliae and $B$. bassiana were the most dominant pathogens on $A$. aegyptium and $M$. anisopliae was determined to be highly virulent during screening tests as a part of research program for the development of a microbial insecticide against locusts and grasshoppers in Africa. (Roditakis et al 2002) also reported that $M$. anisopliae is more virulent than $B$. bassiana at a conidial concentration lower or equal to $10^{6}$ per $\mathrm{ml}$ while being similarly virulent on the first stage nymphs at $10^{7}$ conidia per $\mathrm{ml}$. (Lomer et al 2001) found that the recent development of effective oil formulations of $M$. anisopliae spores opens new possibilities for environmentally safe control operations. Metarhizium biopesticide kills $70 \%$ - 90\% of treated locusts within 14-20 days, with no measurable impact on non-target organisms.

\section{D- Hostathion bait:}

Death rate of $A$. aegyptium adults after $24, \mathrm{hr}$ were 55,60 and $65 \%$ upon exposure to bait at the concentrations of $1.0 \mathrm{~L}, 1.5 \mathrm{~L}$, and $1.75 \mathrm{~L} . \mathrm{ml}$ of Hostathion, respectively, with the consumption of 6.2. 6.4 and 6.5 gr. After 48, hr. the death rates were 60,62 and $69 \%$. with reduced consumption of $6.5,6.6$ and 6.7 gr. After $72 \mathrm{hr}$. these rates increased to 63,70 and $75 \%$ with the consumption of $6.5,6.7$ and 6.8 grams of the bait. Adults death rates were $0 \%$ in the control and consumed 8.5,8.9 and 9.5 grams of the bait in 24, 48 and 72 $\mathrm{hr}$, respectively, with $0.0 \%$ death in the control. Calculated $\mathrm{LC}_{50}$ were 1379.7 , 789.8 and $433.0 \mathrm{ml}$. after 24,48 and $72 \mathrm{hr}$, respectively, (Table 1).

Death rate of $A$. aegyptium adults after 24 , hr were 29,35 and $45 \%$ upon exposure to bait at the concentrations of $\mathrm{LC}_{50}$ of $1.0 \mathrm{~L}, 1.5 \mathrm{~L}$, and $1.75 \mathrm{~L}$. $\mathrm{ml}$ of Hostathion, respectively, with the consumption of 7.0, 6.8 and $6.5 \mathrm{gr}$. After 48, hr. the death rates were 30,38 and $52 \%$.with reductive consumption of 7.5, 6.8 and $6.6 \mathrm{gr}$. After $72 \mathrm{hr}$. these rates increased to 38,42 and $45 \%$ with

Fayoum J. Agric. Res. \& Dev., Vol.25, No.1, January, 2011 
the consumption of 8.0, 6.3 and 6.1 grams of the bait. Adults death rates were $0 \%$ in the control and consumed 18.2, 20.5 and 22.2 grams of the bait in 24, 48 and $72 \mathrm{hr}$, respectively.

\section{D - Field application effects :}

\section{Quick lime bait:}

The death rates of $A$. aegyptium adults after 2 days were 53, 54 and $54 \%$ upon exposure to bait of quick lime at the concentration $2.0,3.0$, and $3.5 \mathrm{~kg}$., respectively. After 4 days the death rates were 58, 60 and 61\%. After 6 days these rates increased to 60,63 and $70 \%$ while Adults death rates were $0 \%$ in the control.

\section{Beauveria bait:}

The death rate of $A$. aegyptium adults after 2 days were $0 \%$ upon exposure to bait at the concentrations of the B. bassiana at the concentration $2 \times 10^{5}, 3 \times 10^{6}$, and $3.5 \times 10^{7}$ spores / ml., respectively. After 4 days the death rates were 45, 48 and $50 \%$. After 6 days these rates increased to 46,50 and $55 \%$ while Adults death rates were $0 \%$ in the control.

\section{Metarhizium bait:}

Death rate of $A$. aegyptium adults after 2 days were $0 \%$ upon exposure to bait at the concentrations of the M.anisopliae at the concentration $2 \times 10^{5}$, $3 \times 10^{6}$, and $3.5 \times 10^{7}$ spores / ml., respectively. After 4 days the death rates were 38,40 and $43 \%$. After 6 days these rates increased to 40, 40 and $53 \%$ while Adults death rates were $0 \%$ in the control.

\section{Hostahion bait:}

Death rate of $A$. aegyptium adults after 2 days were 51, 50 and 53\% upon expose use to prepared bait at the concentrations of Hostathion at the concentration 2, 3, and 3.51. respectively. After 4 days the death rates were 55,55 and $60 \%$. After 6 days these rates increased to 58, 60 and $68 \%$ while Adults death rates were $0 \%$ in the control.

Statistical analysis of the obtained data showed significant differences in reducing $A$. aegyptium at different concentrations of quick lime, the entomopathogens and the chemical insecticide compared with the untreated control.

Obtained results were in agreement with the findings of Ishraga and Magzoub (2009) who reported that the entomopathogenic fungus Metarhizium anisopliae in oil-based formulation is used for control of locusts and grasshoppers and acts through direct contact and Metarhizium spp. have show effective control of a number of target species under a range of natural field conditions.

On the other hand, Tandon et al., (2007) reported that pests have developed resistance to insecticides, biological control using microbial pathogens, particularly fungal pathogens like B.bassiana M. anisopliae and Verticillium lecanii has been explored for a number of pests.

Insecticides were used in wide range against $A$. aegyptium in the field allover the world (Roditakis et al 2002). However, the hazards of using the insecticides were recorded in several researches (Badenes-Perez and Shelton 2006) and (Muhammad Shakur et al 2007) reported that using baits of (Dipterex [trichlorfon] + sugar + rice husk) on permanent plots of potato crop were effective and more persistent for giving healthy products. Hostathion insecticide was used in bait for controlling A. aegyptium, an additional problem for control making it difficult for insecticides to reach their targets (Goeden 1979). But its persistency polluted the soil for long

Fayoum J. Agric. Res. \& Dev., Vol.25, No.1, January, 2011 
Table 3

Fayoum J. Agric. Res. \& Dev., Vol.25, No.1, January, 2011 


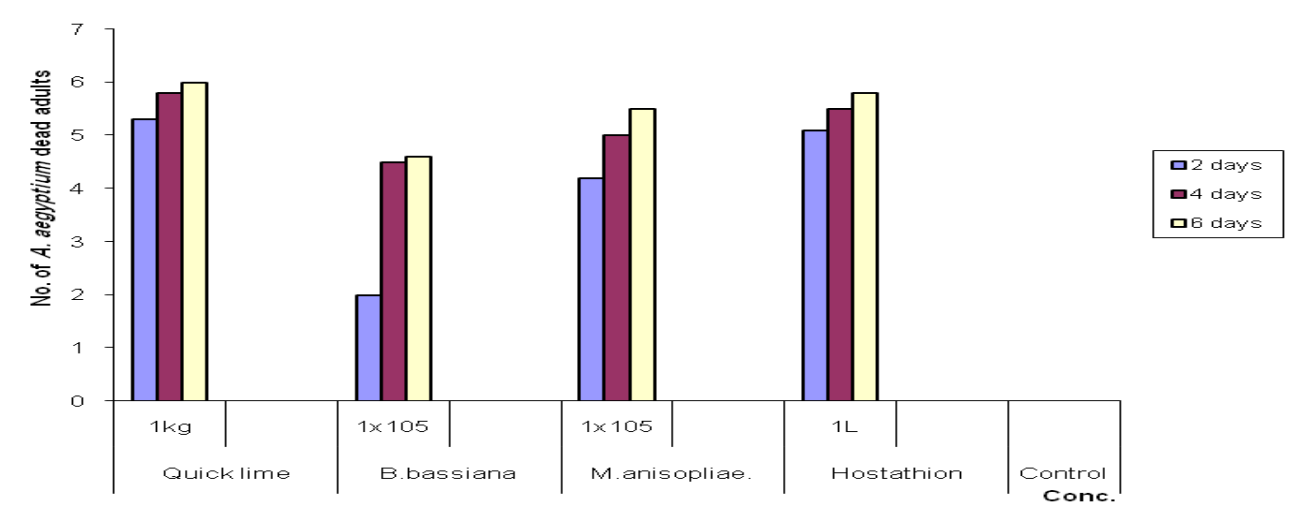

Fig (4): Potency of quick lime B. bassiana, M. anisopliae, and Hostathion against adult of Anacridium aegyptium, in the field at different concentrations.

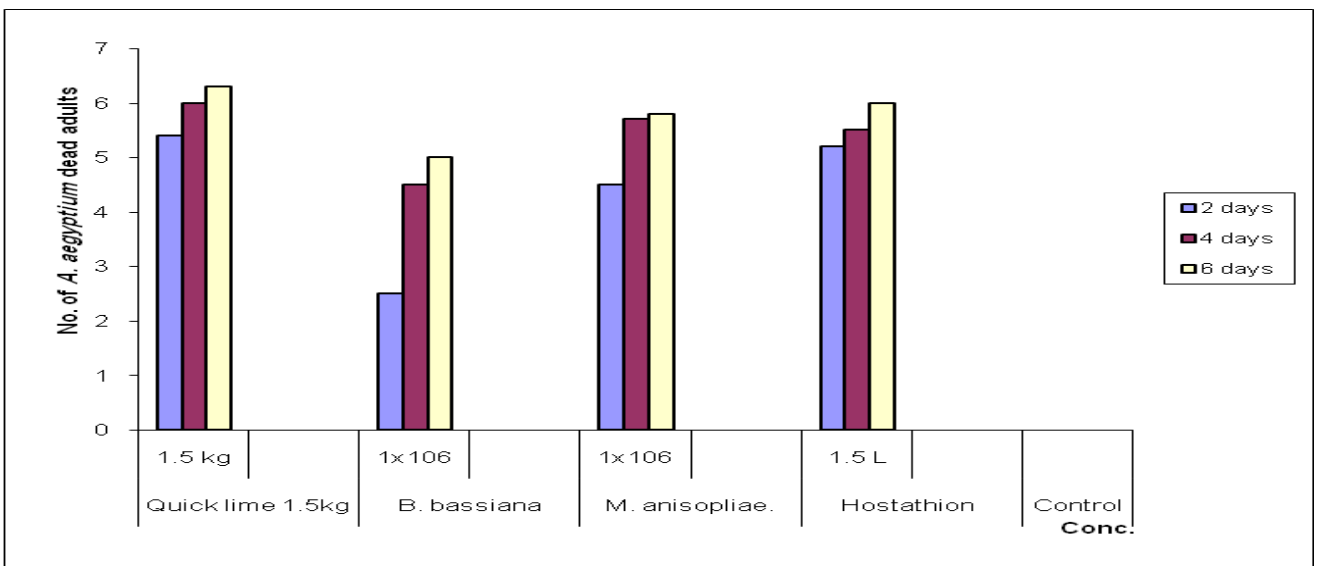

Fig (5): Potency of quick lime B. bassiana, M. anisopliae, and Hostathion against Anacridium aegyptium adults, in the field at different concentrations.

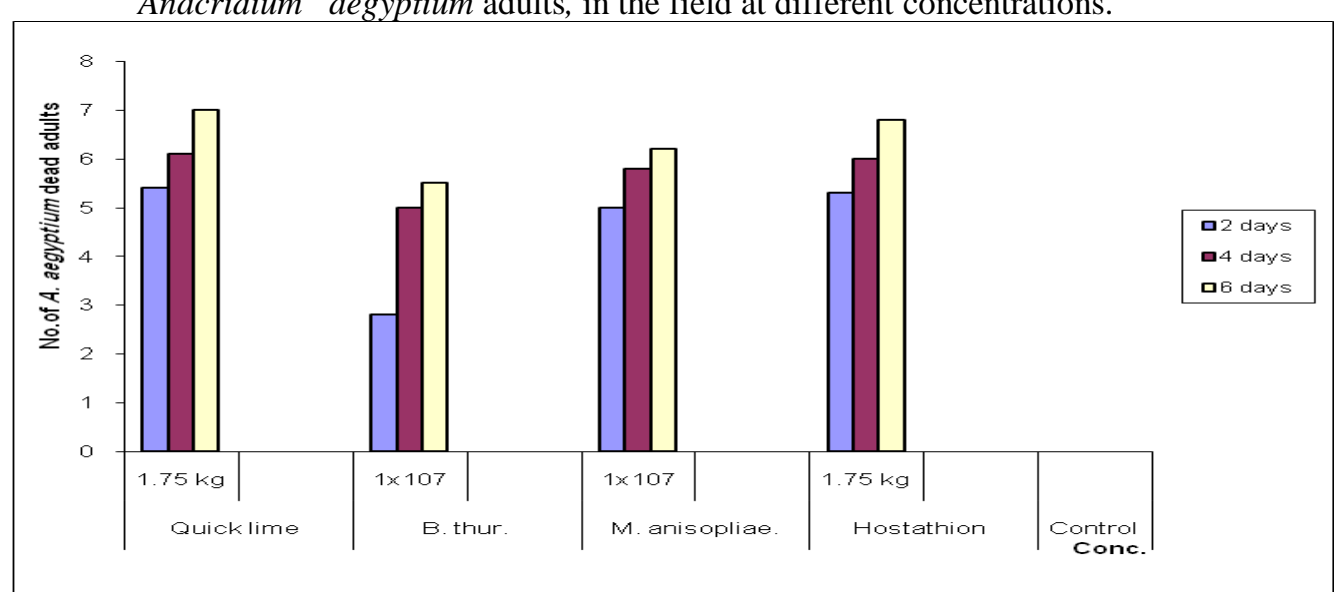

Fig (6): Potency of quick lime B. bassiana, M. anisopliae, and Hostathion against Anacridium aegyptium adults in the field at different concentration.

Fayoum J. Agric. Res. \& Dev., Vol.25, No.1, January, 2011 
time after spraying. Therefore, Quick lime, Hostathion, $M$. anisopliae and $B$. bassiana, achieved semi-hard cake achieved higher mortality after $72 \mathrm{hr}$. in the laboratory and 6 days in the field. Furthermore, quick lime was safety and cheap material for controlling A. aegyptium. Statistical analysis shows that the correlation and regression co-efficient were $(\mathrm{r}=1.5)$

REFERENCES

Anjum Suhail; Ghazala Suhail; Muhammad Khalid Al- Hariri (2001): Some Acridid Grass hoppers belonging to sub-family Cyrtacanthacridinae (Acrididae:Orthoptera) from Pakistan. International .J. of Agric. Biol. 3-1, 43 - 46 Pakistan.

Badenes-Perez, F.R.; and Shelton, A.M. (2006): Pest management and other agricultural practices among farmers growing cruciferous vegetables in the Central and Western highlands of Kenya and the Western Himalayas of India. International Journal of Pest Management 52:4, 303-315. 49 ref USA.

Finny, D.J. (1952): Probit analysis, $3^{\text {rd }}$. edition, Cambridge University Press, pp. 333.

Goeden. G.D (1979): The palearctic insect fauna of milk thistle, Silybum marianum, as a source of biological control agents for California. Env. Ent. 5(2), 345-353.

Ishraga Mohamed El Hassan; and Magzoub O. Bashir (2009): Reduction of Feeding by the gregarious Nymphs of the Dessert Locust Schistocerca gregaria (Forskal), Following Infection by the Fungal Pathogens, Metarhizium anisopliae Var. Acridium. Original Article Jgeb Vol. 7, No. 1, 2009 Sudan.

Lomer, C.J.; Bateman, R.P.; C.J.; Johnson, D.L.; Langewald, J.; Thomas, M. (2001): Biological control of locusts and grasshoppers. Annual Review of Entomology (2001) 46, 667-702

Maud, J. Norris, MRS. O.W. Richards (1965): Reproduction of the grass hopper Anacridium aegyptium L. in the laboratory. Proc, R, Ent, Soc,of Lond.(A). Vol 40, (1-3) pp. 19-29, 1 fig UK.

Muhammad Shakur; Farman Ullah; Muhammad Naem; Muhammad Amin; Saljoqi, A.U.R.; Muhammad Zamin (2007): Effect of various insecticides for the control of potato cutworm (Agrotis ipsilon Huf., Noctuidae: Lepidoptera) at Kalam Swat. Sarhad Journal of Agriculture. 2007. 23: 2, 423-425. 1 ref Pakistan.

Roditakis, N.E.; Kollaros, D. Legakis, A.(2002): Entomopathogens of Anacridium aegyptium L. in crete. Ent.Hel. 14, 5: 10.

Rosa Fugut; and Alain Vey (2004): Comparative analysis of the production of insecticidal and melanizing macromolecules by strains of Beauveria Spp. In vivo studies. J Of Vert. Path. Vol. 8 - 5 -3 p 152-167

Shah, P.A.; and Kooyman, A. Paraiso (1997): Survey for fungal pathogens of locusts and grasshoppers in Africa and the near east. Ent. Soci. of Canada, 129(171) 27-35

Tandon, P.L.; Jalali, S.K.; Poorani, J.; Ramanujam, B.; akthavatsalam, N.; Rabindra, R.J. (2007): Microbial control of sucking pests using entomopathogenic fungi. J. of. Biol.Cont. 2007. 21: Special, 21-28. 30 ref.

SAS Institute (1988): SAS/STAT users Guide, Ver. 6.03. SAS Institute Inc., Cary, North Carolina.

Fayoum J. Agric. Res. \& Dev., Vol.25, No.1, January, 2011 
تأثير بعض الطعوم في مقاومة الطور الكامل للجراد المصري معمليا وحقليا سيد محمد مصطقي الجارحي

معهد بحوث وقاية النباتـ مركز البحوث الزراعية ــ الدقي - جيزة

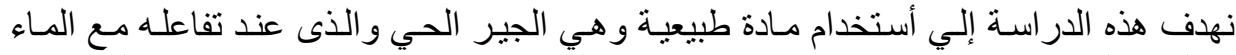

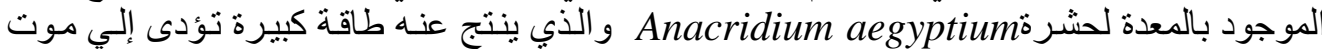

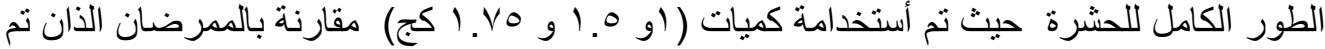

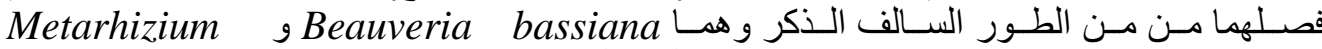
anisopliae

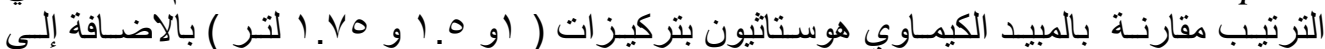

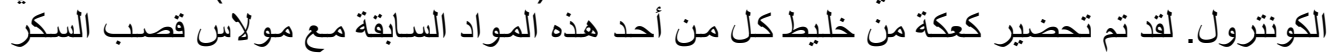

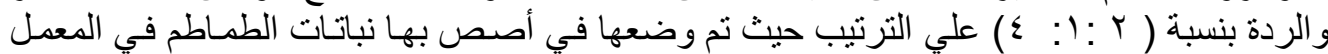

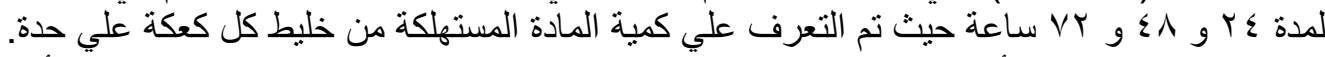

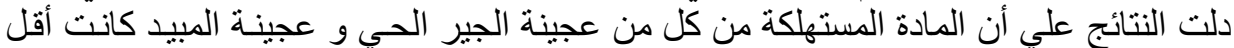

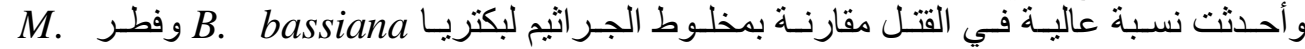
anisopleiae

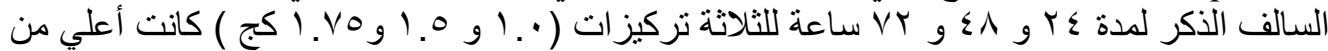

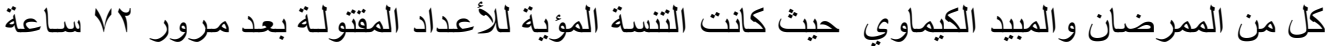

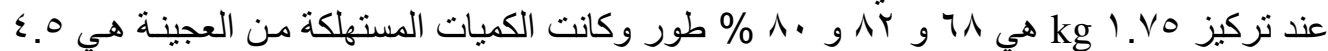

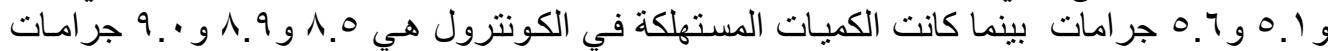

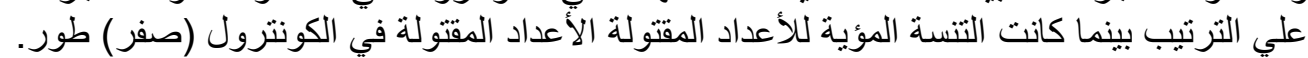

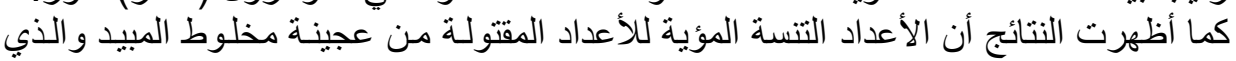

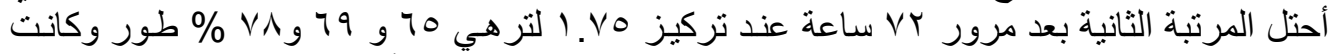

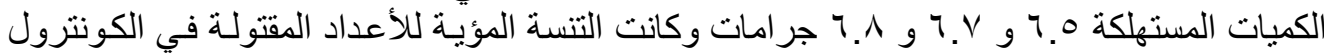

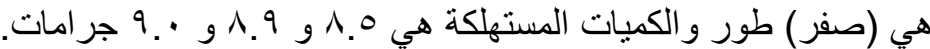

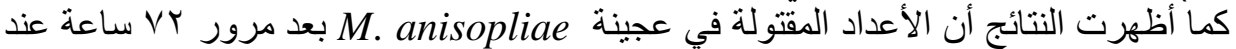

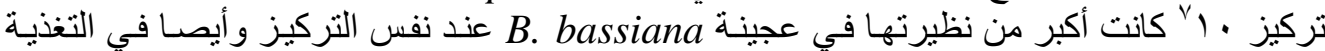

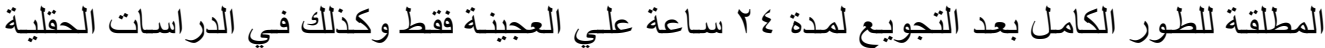

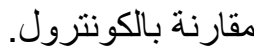

Fayoum J. Agric. Res. \& Dev., Vol.25, No.1, January, 2011 